\title{
Ontogeny of Renal Uric Acid Excretion in the Mongrel Puppy
}

\author{
F. BRUDER STAPLETON, ${ }^{(26)}$ AND BILLY S. ARANT, JR. \\ Department of Pediatrics, University of Tennessee Center for the Health Sciences, Memphis, Tennessee, USA
}

\begin{abstract}
Summary
Renal uric acid excretion was examined in 35 mongrel puppies at 1, 30, 60 and 90 days of age and in seven mature mongrel dogs. Uric acid concentrations in plasma and urine were determined using a uricase fluorometric method. Clearance of inulin increased with postnatal age; however, fractional excretion of uric acid $\left(F_{U_{A}}\right)$ decreased from $83 \%$ at birth to $51 \%$ at 90 days of age ( $r$ $=-0.675, P<0.001$ ). Filtered uric acid and net reabsorption of uric acid increased with postnatal development. The decline in $\mathrm{FE}_{\mathrm{UA}}$ with postnatal age was unrelated to binding of uric acid to plasma proteins or to urine flow rate. A direct correlation was observed between clearance of uric acid $\left(\mathrm{C}_{\mathrm{UA}}\right)$ and clearance of sodium $\left(\mathrm{C}_{\mathrm{Na}}\right)$ during early development $(r=0.48, P<0.001)$. These data indicate that postnatal maturational patterns of renal urate excretion in mongrel puppies are similar to human newborns.
\end{abstract}

\section{Speculation}

The high $\mathrm{FE}_{\mathrm{UA}}$ observed during early postnatal development in the puppy represents decreased tubular reabsorption and/or increased renal tubular secretion of uric acid. In early development, tubular reabsorption of uric acid may be diminished as a result of the high extracellular fluid volume (ECFV). The persistence of high $F E_{U A}$ in puppies at 2 and 3 months of age may be the result of physiologic factors which are different than those in the first day of life. The mongrel puppy appears to be an appropriate animal model for further investigations of renal uric acid transport during human development.

Urate crystals are observed frequently in the urine of neonates, and several investigators have documented a high uric acid concentration in the urines of human newborns $(6,11,13,17)$. Although healthy infants apparently tolerate the large urinary urate load without adverse effects, the high urinary concentration of uric acid may predispose stressed neonates to acute urate nephropathy (6). Passwell et al. (10) evaluated renal urate clearance in 16 infants at $72 \mathrm{~h}$ of age and found that the fractional excretion ranged from $20-59 \%$ of creatinine clearance; normal values in adult humans are 6-12\% (14). Despite the extensive interest in renal transport of uric acid in adult humans and numerous laboratory animals, the physiologic basis for the increased renal urate excretion during early human development is unknown.

Renal handling of uric acid is highly variable among animal species (22), and an appropriate laboratory model for studying renal urate excretion during early development has not been established. We have assessed developmental patterns of renal uric acid excretion in healthy mongrel puppies. The puppy was selected for these studies because of the qualitative similarities in renal urate transport between the mature mongrel dog and manboth exhibit tubular secretion with net reabsorption of uric acid $(9,14,16,23,25)$. Furthermore, knowledge of renal physiology in the developing canine kidney is extensive and developmental patterns for glomerular filtration rate (GFR), sodium excretion and reabsorption of bicarbonate, phosphate and glucose in the puppy have been found similar to the human neonate $(1,3,8)$. In this report, we have defined maturational changes in renal excretion of uric acid in the mongrel puppy during the first 90 days of life. The mongrel puppy appears to be a suitable model for future studies to gain insights into urate transport during postnatal human development.

\section{MATERIALS AND METHODS}

Studies were performed in 35 healthy mongrel puppies at ages $1,30,60$ and 90 days of age and in seven adult dogs. On the day of study, puppies were separated from the litter $1 \mathrm{~h}$ prior to the experiment and were anesthetized with pentobarbital sodium (15$30 \mathrm{mg} / \mathrm{kg}$ ) administered initially and maintained as intermittent boluses. Animals were placed on a heated operating table and ventilated via a tracheostomy with a small animal respirator (model 663, Harvard Apparatus, Millis, MA) to maintain arterial blood $\mathrm{pH}, \mathrm{pCO}_{2}$ and $\mathrm{PO}_{2}$ within the range of normal values. Solutions were infused through a PE-50 catheter inserted into the superior vena cava through the external jugular vein. Mean arterial blood pressure (MABP) was monitored and blood samples were obtained through a PE-50 catheter placed into the abdominal aorta through the left femoral artery. Urine was collected through catheters placed through a suprapubic incision into the ureters to the level of the renal pelvis with urine volume determined by weight. Stability of 42 animals was determined by maintenance of body weight within $3 \%$ of initial weight, pH between 7.35 and 7.45 , hematocrit within $3 \%$ of initial values and MABP within $6 \%$ of initial readings. Nine animals were rejected as failing to meet these criteria. Urine and plasma samples were collected on ice, quickly refrigerated and then placed in a freezer until analyses for uric acid and sodium were performed. Erythrocytes from each blood sample were returned to the animal to maintain the hematocrit near control values. GFR was determined using the renal clearance of $\left[{ }^{3} \mathrm{H}\right]$-inulin $\left(\mathrm{C}_{\mathrm{IN}}\right)$ as previously described (1). Following an equilibration period of $45 \mathrm{~min}$, three $15 \mathrm{~min}$ urine collection periods were made and arterial blood samples were drawn at the midpoint of each period. Sodium and uric acid were determined on each sample. Values for clearance of uric acid $\left(\mathrm{C}_{U A}\right)$, clearance of sodium $\left(\mathrm{C}_{\mathrm{Na}_{\mathrm{a}}}\right)$, fractional excretion of uric acid $\left(\mathrm{FE}_{\mathrm{UA}_{A}}\right)$ and fractional excretion of sodium $\left(\mathrm{FE}_{\mathrm{Na}}\right)$ were determined as the mean of three clearance periods. Sodium values were determined on a model 51 flame photometer (Coleman Instruments, OakBrook, IL).

Uric acid was determined by a modification of the fluorometric method of Kamoun et al. (4). Samples and standards $(50 \mu \mathrm{l})$ were deproteinized in $500 \mu \mathrm{l}$ of $0.01 \mathrm{M}$ acetic acid by heating to $95^{\circ} \mathrm{C}$ for $15 \mathrm{~min}$ then centrifuging for $10 \mathrm{~min}$. Deproteinized samples $(200 \mu \mathrm{l})$ were added to $200 \mu \mathrm{l}$ of $0.1 \mathrm{M}$ phosphate buffer pH 7.4 in duplicate. Uricase, Aspergillus flavus, 0.03 units (BoehringerMannheim $15 \mathrm{U} / \mathrm{mg}$ protein) was added to one tube. Each tube was agitated and incubated at room temperature for $30 \mathrm{~min}$ with

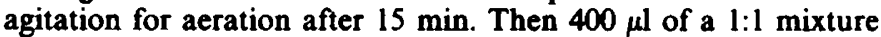
of horseradish peroxidase (Sigma) $1 \mathrm{mg} / \mathrm{ml}$ and $p$-hydroxyphenyl acetic acid (Sigma) $3.7 \mathrm{mg} / \mathrm{ml}$ was added to all samples. The 
cuvettes were then agitated and incubated at $37^{\circ} \mathrm{C}$ for $30 \mathrm{~min}$. After incubation, $3 \mathrm{ml}$ of phosphate buffer $0.1 \mathrm{M}, \mathrm{pH} 10.5$ was added to all cuvettes. Fluorescence for uric acid standards and specimens was determined on a fluorometer (Turner model 110) with excitation maximum at $317 \mathrm{~nm}$ and fluorescence maximum at $414 \mathrm{~nm}$.

To determine the degree of binding of urate to plasma proteins, equilibration dialysis experiments were performed as described by Simken (19). Cellophane dialysis tubing ( $1 / 2$ inch diameter) was heated to $100^{\circ} \mathrm{C}$ in distilled water and washed repeatedly with distilled water. One $\mathrm{ml}$ serum samples were tied in dialysis tubing and then dialyzed at $37^{\circ} \mathrm{C}$ in 1 liter of solution containing $0.05 \mathrm{M}$ sodium phosphate buffer, pH 7.4 containing $5 \mathrm{mg} \%$ uric acid, 5 $\mathrm{mg} \%$ sodium azide and trace amounts of 2-[ $\left.{ }^{14} \mathrm{C}\right]$-uric acid (Amersham). After $30 \mathrm{~h}, 1.0 \mathrm{ml}$ aliquots of both serum and bath were counted in duplicate with correction for quenching when equilibrium had been reached. Binding of uric acid to plasma protein would be suggested if the isotope preferentially accumulated in the serum sample. No correction was made for the Gibbs-Donnan effect. Dialysis studies were performed in serum samples from three 1-day-old puppies and from three adult dogs (Table 1). No accumulation of isotope occurred in the serum samples thus suggesting that no appreciable binding of uric acid occurred in either age group.

Statistical analysis of data as functions of age, urinary sodium excretion and urine flow rate were determined by the least squares method. The Student's $t$ test for paired and unpaired data was

Table 1. Dialysis experiments in serum samples from three puppies and three adult dogs. Serum/Bath ratio is the ratio of counts in the serum and dialysis bath

\begin{tabular}{llcc}
\hline Age & $n$ & Serum/Bath & Range \\
\hline 1-Day-old puppies & 3 & 0.98 & $0.95-1.03$ \\
Adults & 3 & 1.03 & $1.02-1.05$ \\
\hline
\end{tabular}

utilized to compare uricase techniques and mean values between puppies of different age groups. Adult dogs are not included in age-related analyses.

\section{RESULTS}

The fluorometric method was compared with the enzymatic spectrophotometric method of Praetorius and Paulson (12) in 21 serum samples (uric acid concentrations $0.79-10.8 \mathrm{mg} / \mathrm{dl}$ ) and in 22 urine samples. The relationship between the fluorometric technique $(y)$ and the spectrophotometric technique $(x)$ for all samples was $\mathrm{y}=0.137+0.959 \mathrm{x}, r=0.998, P<0.001$ (Fig. 1), for serum samples was $\mathrm{y}=1.03 \mathrm{x}-0.0027, r=0.997, P<0.001$ (Fig. 2), and for urine samples was $\mathrm{y}=0.967 \mathrm{x}-0.293, r=0.996, P<0.001$. The mean difference between samples using the two techniques was $3.76 \% \pm 0.47 \%$ S.E. Recovery of small quantities of uric acid with the fluorometric technique was determined in 65 aqueous standards (uric acid concentration 0.198 to $1.13 \mathrm{mg} / \mathrm{dl}$ ). The fluorometric technique yielded $99.45 \%$ recovery (range $85-110 \%$, S.E. $\pm 0.70 \%$ ). Precision of the fluorometric method was assessed by comparing two consecutive plasma determinations in 20 consecutive puppies and adult dogs. The mean difference between plasma uric acid (PUA) concentrations was $0.023 \mathrm{mg} / \mathrm{dl} \pm 0.006$ S.E. When this difference was expressed as a \% of the lowest plasma value, the mean was $7.3 \% \pm 1.6 \%$ S.E.

Data from studies in puppies at $1,30,60$ and 90 days are compared with adult dogs in Table 2 . Body weight $(r=0.993)$, MABP $(r=0.821)$, and dry kidney weight $(r=0.878)$, increased with postnatal age $(P<0.001)$. A direct relationship between $C_{\text {IN }}$ and postnatal age was observed $(\mathrm{y}=0.965+0.132 \mathrm{x}, r=0.697, P$ $<0.001$ ), but by 90 days, $C_{\text {IN }}$ was still less than mean adult values $(P<0.001)$.

PUA decreased with age $(y=0.781-0.007 x, r=0.595, P<$ 0.001 ) (Table 2). The greatest reduction in PUA $(0.90-0.41 \mathrm{mg} /$ dl) occurred between 1 and 30 days of age. PUA at 90 days was higher than adult values, $P<0.001$. Filtered uric acid (PUA $\times$

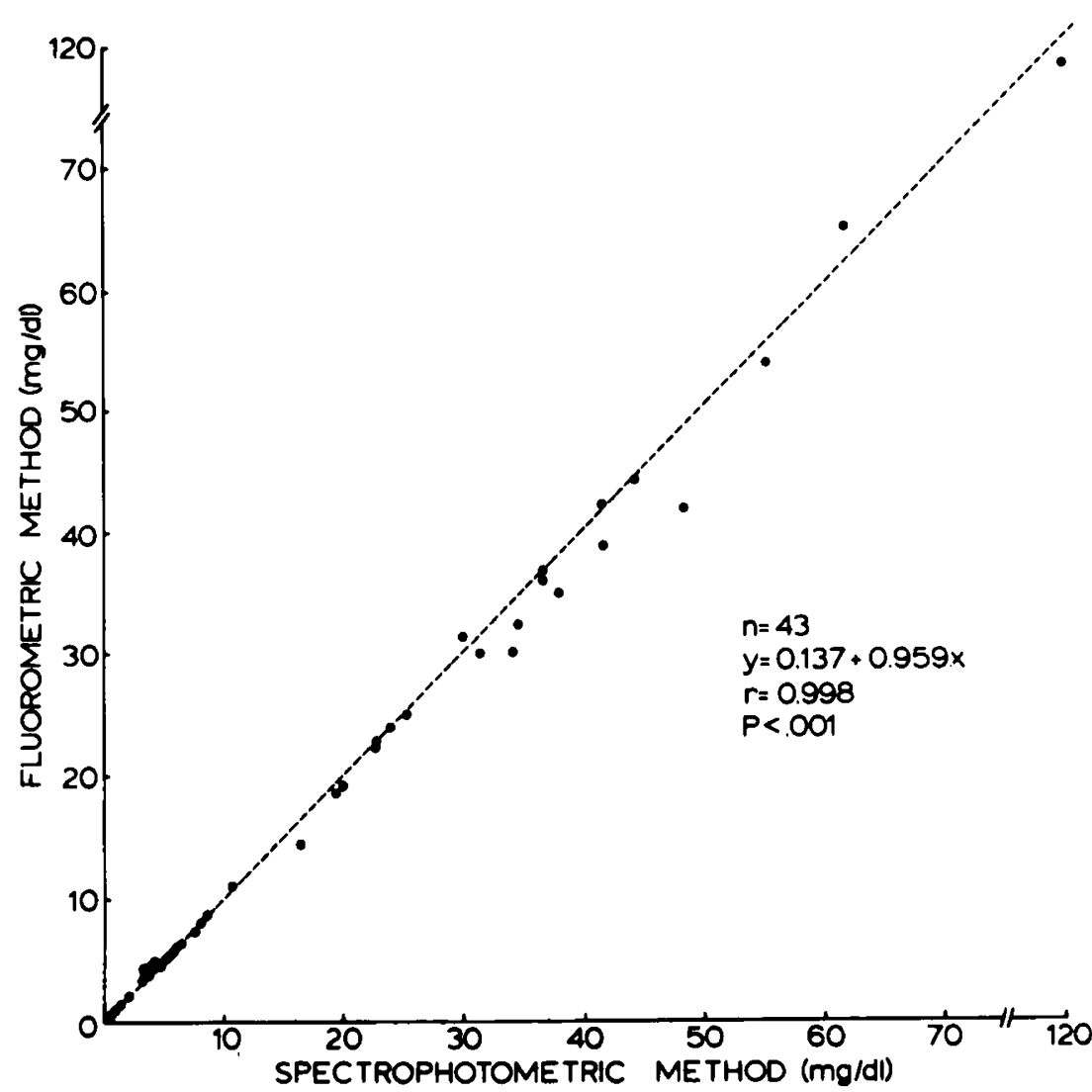

Fig. 1. Spectrophotometric and fluorometric determinations of uric acid are compared in $\mathbf{4 3}$ plasma and urine samples. The broken line represents the line of identity. 
$\left.C_{\text {IN }}\right)$ increased with postnatal age $(y=0.0062+0.0004 x, r=0.731$, $P<0.001)$. PUA in the one day old puppies $(0.90 \mathrm{mg} / \mathrm{dl})$ was greater than mean maternal PUA values $(0.25 \mathrm{mg} / \mathrm{dl})$.

$\mathrm{C}_{U A}$ increased with postnatal age $(\mathrm{y}=0.799+0.074 \mathrm{x}, r=0.842$, $P<0.001)$ and did not vary with urine flow rate $(r=-0.26, P>$ $0.4)$. $F E_{U A}$, however, decreased with postnatal age $(y=$ $0.827-0.0039 \mathrm{x}, r=-0.675, P<0.001$ ) (Fig. 3). $\mathrm{FE}_{\mathrm{UA}}$ was highest in puppies on the first day of life; in fact, one puppy actually demonstrated net secretion of uric acid. Although $\mathrm{FE}_{\mathrm{UA}}$ at 90 days was less than at 60 days, the difference was not statistically different. $\mathrm{FE}_{\mathrm{UA}}$ in puppies studied at 90 days of age was greater than mean values for $\mathrm{FE}_{\mathrm{UA}}$ in the adult dogs $(P<0.01)$ (Table 2$)$. The age-related decrease in $F_{U_{A}}$ occurred with an increasing load of filtered uric acid. Net reabsorption of uric acid (filtered uric acid - excreted uric acid) increased from $0.2-22.2 \mu \mathrm{g} / \mathrm{min}$ in the first 90 days of life $(r=0.609, P<0.001)$. No consistent relationship between $\mathrm{FE}_{\mathrm{Na}}$ and postnatal age was observed, although a direct relationship occurred between $\mathrm{C}_{\mathrm{UA}}$ and $\mathrm{C}_{\mathrm{Na}}(\mathrm{y}=$ $2.38+0.013 \mathrm{x}, r=0.48, P<0.001$ ) (Fig. 4).

\section{DISCUSSION}

The relevance of data concerning renal excretion of uric acid in laboratory studies to human renal physiology must be viewed with caution. In general, renal excretion of uric acid involves filtration at the glomerulus with reabsorption and/or secretion by the renal tubule; however, renal urate transport processes vary greatly among species (22). Weiner (22) has categorized animals according to the qualitative direction(s) of uric acid transport and has grouped the mongrel dog with man since both exhibit net tubular reabsorption with definite evidence for renal tubular secretion. Studies in mongrel puppies, therefore, might provide relevant new insights into the understanding of renal uric acid transport during early human development.

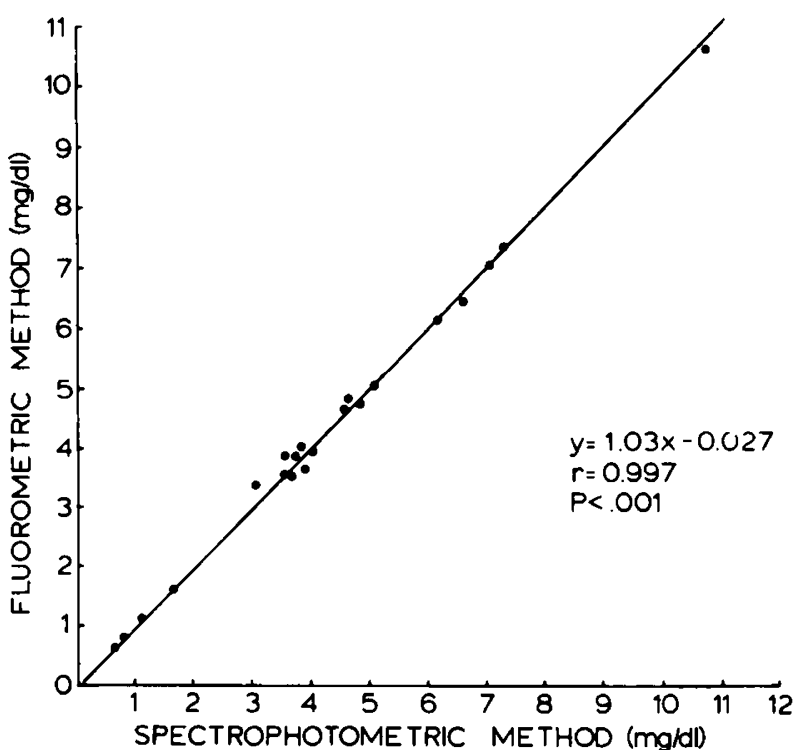

Fig. 2. Spectrophotometric and fluorometric determinations of uric acid in 21 serum samples. The solid line represents the line of identity.
Our data in puppies show that in spite of increased filtered load of uric acid and increasing $\mathrm{C}_{\mathrm{UA}}, \mathrm{FE}_{\mathrm{UA}}$ declines from $83.2 \%-51.2 \%$ during the first 3 months of life. Furthermore, $F E_{U A}$ at 3 months of age remains higher than $F_{U_{A}}$ in mature dogs $(44.4 \% \pm 6.0)$. Similar values for $\mathrm{FE}_{\mathrm{UA}}(49.1 \% \pm 4.8)$ in mature dogs have been reported by Roch-Ramel et al. (16). The decline in FE ${ }_{U A}$ observed in our studies cannot be attributed to decreased GFR or to binding of uric acid to plasma proteins. The absence of protein-binding of urate in our studies substantiates an earlier report by Simken (19)

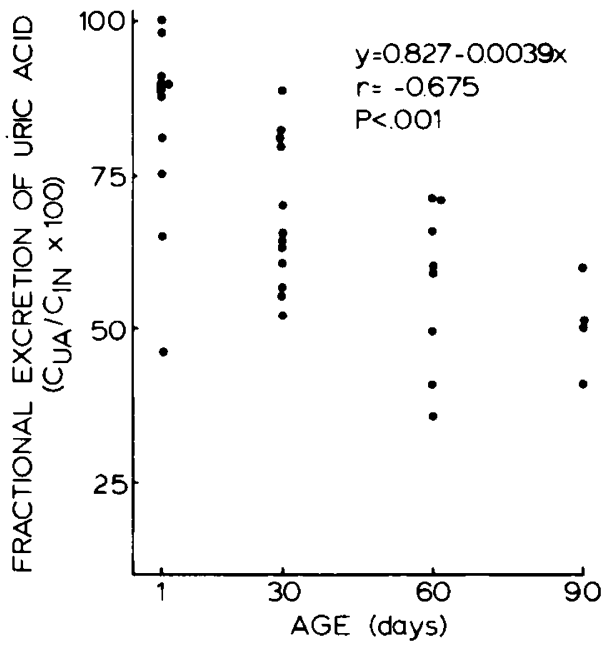

Fig. 3. Fractional excretion of uric acid $\left(\mathrm{FE}_{\left.U_{A}\right)}\right.$ is shown for 35 puppies. Each point represents the mean of three clearance periods in each puppy.

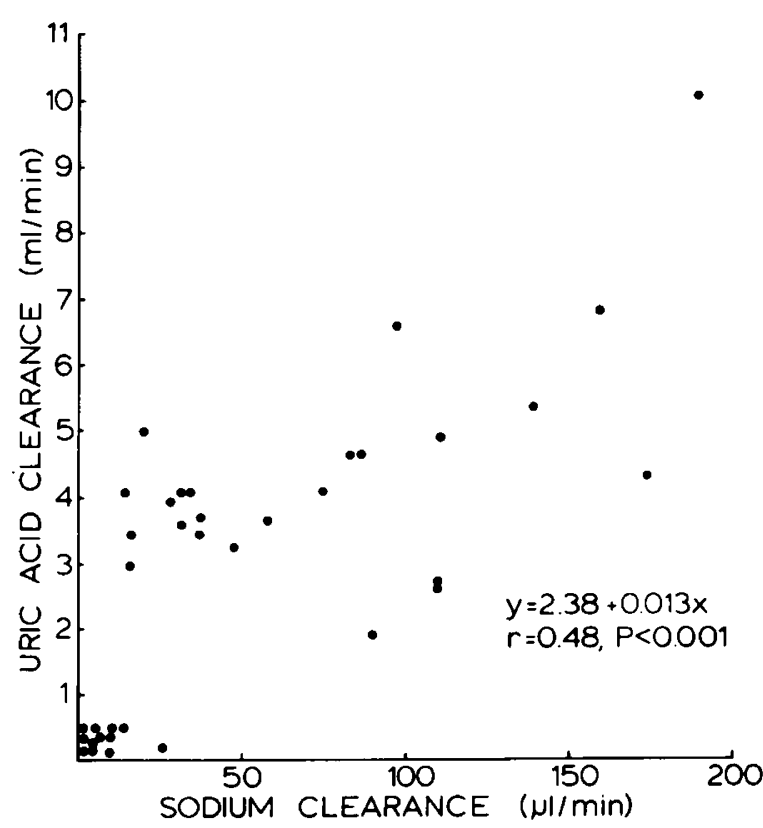

Fig. 4. The relationship between clearance of sodium $\left(\mathrm{C}_{\mathrm{Na}_{\mathrm{a}}}\right)$ and clearance of uric acid $\left(\mathrm{C}_{U A}\right)$ in puppies is shown. Each point represents the mean of three clearance periods.

Table 2. Summary of data from puppies and adult mongrel dogs. Abbreviations are given in text

\begin{tabular}{|c|c|c|c|c|c|c|c|c|c|c|c|}
\hline $\begin{array}{l}\text { Age } \\
\text { days }\end{array}$ & $n$ & $\begin{array}{c}\text { Body Weight } \\
\text { kg }\end{array}$ & $\begin{array}{c}\text { Dry Kidney } \\
\text { Weight } \\
\text { g }\end{array}$ & $\begin{array}{l}\text { MABP } \\
\mathrm{mm} \mathrm{Hg}\end{array}$ & $\begin{array}{c}\mathrm{C}_{\mathrm{IN}} \\
\mathrm{ml} / \mathrm{min}\end{array}$ & $\underset{\%}{\mathrm{FE}_{\mathrm{N}}}$ & $\underset{\mathrm{mg} / \mathrm{dl}}{\mathrm{PuA}_{\mathrm{A}}}$ & $\begin{array}{c}\mathrm{C}_{\mathrm{UA}} \\
\mathrm{ml} / \mathrm{min}\end{array}$ & $\underset{\%}{\mathbf{F E}_{\mathbf{U A}}}$ & $\begin{array}{c}\text { Filtered } \\
\text { UA } \\
\mu \mathrm{g} / \mathrm{min}\end{array}$ & $\begin{array}{l}\text { Net Reab- } \\
\text { sorbed } \\
\text { UA } \\
\mu \mathrm{g} / \mathrm{min}\end{array}$ \\
\hline I & 11 & $0.35 \pm 0.03^{1}$ & $0.77 \pm 0.04$ & $40.9 \pm 2.1$ & $0.50 \pm 0.05$ & $1.48 \pm 0.63$ & $0.90 \pm 0.12$ & $0.39 \pm 0.04$ & $83.21 \pm 4.70$ & $4.1 \pm 0.65$ & $0.2 \pm 0.06$ \\
\hline 30 & 12 & $1.66 \pm 0.07$ & $4.46 \pm 0.14$ & $73.3 \pm 2.2$ & $5.27 \pm 0.30$ & $0.55 \pm 0.08$ & $0.41 \pm 0.06$ & $3.72 \pm 0.16$ & $69.02 \pm 3.42$ & $23.0 \pm 2.41$ & $8.8 \pm 0.18$ \\
\hline 60 & 8 & $2.30 \pm 0.23$ & $3.70 \pm 0.23$ & $77.3 \pm 2.5$ & $9.27 \pm 0.86$ & $1.14 \pm 0.23$ & $0.31 \pm 0.04$ & $5.54 \pm 0.64$ & $57.13 \pm 4.04$ & $28.0 \pm 3.52$ & $11.9 \pm 0.15$ \\
\hline 90 & 4 & $3.40 \pm 0.28$ & $5.41 \pm 0.52$ & $81.3 \pm 9.1$ & $12.15 \pm 2.66$ & $1.03 \pm 0.19$ & $0.34 \pm 0.08$ & $6.30 \pm 1.30$ & $51.22 \pm 3.02$ & $42.0 \pm 8.01$ & $22.2 \pm 0.22$ \\
\hline Adult & 7 & $15.61 \pm 2.56$ & $14.78 \pm 2.95$ & $106.4 \pm 3.6$ & $40.49 \pm 5.66$ & $0.82 \pm 0.14$ & $0.21 \pm 0.04$ & $20.16 \pm 4.12$ & $44.41 \pm 6.01$ & $88.9 \pm 1.92$ & $39.0 \pm 1.91$ \\
\hline
\end{tabular}

${ }^{1}$ Mean \pm S.E. 
who found no evidence for protein binding of uric acid in adult mongrel dogs. Urine flow rate, a factor which may affect proximal urate reabsorption (18), did not appear to explain the developmental patterns of renal uric acid excretion in our studies. Since the decline in $\mathrm{FE}_{\mathrm{UA}}$ during development was demonstrable among littermates of varying ages, it appears unlikely that inter-litter variations in renal handling of uric acid account for our findings.

Decreased renal tubular reabsorption of uric acid has been hypothesized to account for the high $\mathrm{FE}_{\mathrm{UA}}$ in human neonates (10). The importance of ECFV upon renal tubular reabsorption in the puppy has been emphasized by Moore et al. (8) who demonstrated an increase in the bicarbonate threshold during contraction of the ECFV and by Arant (1) who showed that renal excretion of glucose increased during saline loading. Expansion of the ECFV has also been shown to increase FE $\mathrm{UA}_{\mathrm{A}}$ in man (5) and in the rat (25). One might speculate that a normally expanded ECFV in the neonatal puppy might play a role in the high $F_{U A}$ observed in early development (2). A direct relationship between $\mathrm{C}_{\mathrm{UA}}$ and $\mathrm{C}_{\mathrm{Na}}$ was observed in these studies. These data suggest that factors which influence sodium excretion might also affect renal tubular handling of uric acid; however, sodium is reabsorbed in both the proximal and distal tubule while renal uric acid transport in the mongrel dog occurs in the proximal tubule (16). It is unknown whether the same physiologic factors account for the decrease in $\mathrm{FE}_{\mathrm{UA}}$ values between each postnatal age of study.

PUA also decreased during development, particularly during the first postnatal month. The decline in PUA observed in the first postnatal month occurred despite an increase in net tubular reabsorption of urate. The elevated PUA values during the first day of life, which were higher than maternal values, may reflect decreased extra-renal disposal of uric acid in the puppy or, more likely, decreased activity of hepatic uricase. In this regard, Mendell and Mitchell (7) observed that hepatic uricase (normally present in adult pigs) was not detectable in the livers of the newborn piglets. Hepatic uricase is present in adult mongrel dogs (24); however, no data are available concerning hepatic uricase in puppies. The concentrations of uric acid in the plasma of mature inongrel dogs which we observed were similar to values observed by $\mathrm{Y}_{i}$. al. (24).

One obs scle $\mathrm{t} r$ nvestigations of renal $\mathrm{C}_{\mathrm{UA}}$ in animals has been the accurate measurement of low concentrations of uric acid in the plasma. We have been unable to reliably measure uric acid at concentrations less than $1 \mathrm{mg} / \mathrm{dl}$ (adult mongrel dog PUA $=0.2$ $\mathrm{mg} / \mathrm{dl}$ ) with the standard uricase spectrophotometric method (12). For this reason, previous clearance studies in dogs have often been obtained during urate loading which artificially elevates the PUA concentration. Roch-Ramel and Peters (15) have recently reviewed methods for measuring low concentrations of uric acid. Fluorometric techniques have been utilized previously to measure small quantities of uric acid (4). We have modified the fluorometric technique of Kamoun et al. (4) to measure uric acid and have found this method to correlate well with the standard uricase spectrophotometric technique (12).

The maturational patterns of renal urate excretion during development in the puppy are similar to those reported in human newborns and older children $(20,21)$. The value of the puppy as a model for the study of postnatal renal maturation has been appreciated previously by numerous investigators. Our data indicate that the puppy also may serve as an appropriate animal model for future investigations of renal urate transport during development.

\section{REFERENCES AND NOTES}

1. Arant, B. S., Jr.: Glomerulotubular balance following saline loading in the developing canine kidney. Am. J. Physiol., 235: F417 (1978)

2. Arant, B. S., Jr.: The effect of $F E_{\mathrm{Na}_{a}}$ and extracellular volume expansion on GT balance in the developing canine kidney. Pediatr. Res., 10: 435 (1976).

3. Horster, M., and Valtin, H.: Postnatal development of renal function: micropuncture and clearance studies in the dog. J. Clin. Invest., 50: 779 (1971).

4. Kamoun, P., Lafourcade, G., and Jerome, H.: Ultramicromethod for determination of plasma uric acid. Clin. Chem., 22: 964 (1976).

5. Manuel, M. A., and Steele, T. H.: Pyrazinamide suppression of the uricosuric response to sodium chloride infusion. J. Lab. Clin. Med., 83: 417 (1974).

6. Manzke, H., Eigster, G., Harms, D., Dörner, K., and Grunitz, J.: Uric acid infarctions in the kidneys of newborn infants. Eur. J. Paediatr., J26: 825 (1978).

7. Mendel, L. B., and Mitchell, P. H.: Chemical studies on growth II. The enzymes involved in purine metabolism in the embryo. Am. J. Physiol., 20: 97 (1907).

8. Moore, E. S., Fine, B. P., Satrosook, S. S., Vergel, Z. M., and Edelmann, C. M. Jr.: Renal reabsorption of bicarbonate in puppies: effect of extracellular volume contraction on the renal threshold for bicarbonate. Pediatr. Res., 6: 859 (1972).

9. Mudge, G. H., Cuceli, J., Platts, M., O'Connell, J. M. B., and Berndt, W. O.: Renal excretion of uric acid in the dog. Am. J. Physiol., 215: 404 (1968).

10. Paswell, J. H., Modan, M., Brish, M., and Boichus, H.: Fractional excretion of uric acid in infancy and childhood-index of tubular maturation. Arch. Dis. Child., 48: 878 (1974).

11. Poulsen, H.: Uric acid in blood and urine of infants. Acta Physiol. Scand., 33: 372 (1955).

12. Praetorius, E., and Paulson, H.: Enzymatic determination of uric acid. Scand. J. Clin. Lab. Invest., 5: 273 (1953).

13. Ravio, K. E.: Neonatal hyperuricemia. J. Pediatr., 88: 625 (1976).

14. Rieselbach, R. E., and Steele, T. H.: Influence of the kidney upon urate homeostasis in health and disease. Am. J. Med., 56: 665 (1974).

15. Roch-Ramel, F., and Peters, G.: Sites and mechanisms of intrarenal uric acid transports. Proc. Int. Congr. Nephrol. Montreal., 7th, 617 (1978).

16. Roch-Ramel, F., Wong, N. L. M., and Dirks, J. H.: Renal excretion of urate in mongrel and Dalmatian dogs: a micropuncture study. Am. J. Physiol., 2jl: 326 (1976).

17. Schloss, O. M., and Crawford, J. L.: The metabolism of nitrogen, phosphorus and the purine substances in the newborn with special reference to causation of uric acid infarcts of the kidney. Am. J. Dis. Child., I: 203 (1911).

18. Senekjian, H. O., Knight, T. F., Sansom, S. C., and Weinman, E. J.: Effect of flow rate and the extracellular fluid volume on proximal urate and water reabsorption. Kidney Int., 17: 155 (1980).

19. Simken, P. A.: Uric acid binding to serum proteins: Differences among species. Proc. Soc. Exp. Biol. Med., 136: 604 (1977).

20. Stapleton, F. B., and Korones, S. B.: Intra and extrauterine development of renal uric acid clearance in human neonates. Pediatr. Res., 15: (1981) (In press).

21. Stapleton, F. B., Linshaw, M. A., Hassenein, K., and Gruskin, A. B.: Uric acid excretion in normal children. J. Pediatr., 92: 911 (1978).

22. Weiner, I. M.: Urate transport in the nephron. Am. J. Physiol., 237: F85 (1979)

23. Yu, T., Berger, L., Kupfer, S., and Gutman, A. B.: Tubular secretion of urate in the dog. Am. J. Physiol., 199: 1199 (1960).

24. Yu, T. F., Gutman, A. B., Berger, L., and Kaung, C.: Low uricase activity in the Dalmatian dog simulated in mongrels given oxonic acid. Am. J. Physiol., 215: 411 (1968).

25. Zins, G. R., and Weiner, I. M.: Bidirectional urate transport limited to the proximal tubule in dogs. Am. J. Physiol., 215: 411 (1968).

26. Requests for reprints should be addressed to: Dr. F. Bruder Stapleton, Pediatric Research Laboratory, 951 Court Ave., Room 555 Dobbs, Memphis, TN 38163.

27. This research was supported by the University of Tennessee Center for the Health Sciences New Faculty Grant H-00047.

28. Received for publication February $2,1981$.

29. Accepted for publication June 1,1981 . 